\title{
KOMUNIKASI INTERPERSONAL TERHADAP DOSEN PEMBIMBING DAN KETAKUTAN AKAN KEGAGALAN MAHASISWA DALAM MENYELESAIKAN SKRIPSI
}

\author{
Lussy Dwiutami Wahyuni* \\ Fakhriani Isti Irsalina** \\ *Jurusan Psikologi, Universitas Negeri Jakarta \\ **Jurusan Psikologi, Universitas Negeri Jakarta
}

DOI: https://doi.org/10.21009/JPPP.032.07

Alamat Korespondensi:

lussysf@unj.ac.id

\begin{abstract}
This study aims to determine the relationship between interpersonal communication to supervisors with the studennts fear of failure in completing undergraduated thesis. The research approach used in this study is quantitative, with the correlation analysis method. Fear of failure is measured by the Performance Failure Appraisal Inventory (PFAI) scale of David E. Conroy (2001) with a reliability of 0.98, while the interpersonal communication scale is adapted from Evi Zuhara (2014) thesis from Universitas Pendidikan Indonesia with a reliability of 0,86. The respondents in this study are 136 students, who are completing the undergraduated thesis in Universitas Negeri Jakarta. The findings indicate there is a relationship between interpersonal communication towards the students fear of failure. The value of correlation coefficient generated equal to 0,240 with significance of 0,005 at the significance level of 5\%. It can be concluded that there is a negative relationship between interpersonal communication to supervisors with students fear of failure in completing undergraduated thesis.
\end{abstract}

\section{Keywords}

interpersonal communication, fear of failure, students

\section{Pendahuluan}

Menurut Kamus Besar Bahasa Indonesia (KBBI) skripsi adalah karangan ilmiah yang wajib ditulis oleh mahasiswa sebagai bagian dari persyaratan akhir pendidikan akademisnya (Departemen Pendidikan Nasional, 2015). Skripsi menjadi syarat bagi mahasiswa untuk meraih gelar akademiknya sekaligus menjadi tolok ukur untuk melihat sejauh mana pemahaman mahasiswa terhadap ilmu yang telah dipelajarinya melalui penelitian yang dilakukan berdasarkan fenomena atau permasalahan yang terjadi. Dalam melakukan penelitiannya mahasiswa dituntut untuk mampu menyelesaikan permasalahan secara ilmiah dan disusun secara sistematis sesuai dengan kaidah yang berlaku. Tuntutan tersebut membutuhkan kemampuan mahasiswa untuk mampu berpikir kritis, mulai dari merumuskan tema, latar belakang masalah, melakukan penelitian, menganalisa hasil yang didapat hingga penarikan kesimpulan. Hal ini dikarenakan mahasiswa yang berdasarkan perkembangannya termasuk dalam kelompok remaja akhir, sudah harus memiliki kemampuan berpikir yang lebih sempurna dan pandangan yang realistis agar mampu memecahkan berbagai permasalahan secara matang dan realistis (AlMighwar, 2006: 71). Besarnya tuntutan yang akan dihadapi sering kali menjadikan skripsi sebagai hal yang 
menakutkan bagi mahasiswa tingkat akhir. Dijadikannya skripsi sebagai syarat dalam kelulusan akademik menyebabkan adanya perasaan cemas, gelisah dan ketakutan tersendiri yang dirasakan mahasiswa bila tidak mampu menyelesaikannya. Dyckman (2005) menyatakan bahwa pada mahasiswa yang sedang melakukan penelitian untuk tugas akhirnya, seperti disertasi, kecemasan akademik dapat menciptakan hambatan serius seperti terhambatnya proses penelitian hingga terjadinya drop out.

Berdasarkan hasil survei pertama yang dilakukan pada tanggal 1 - 3 Maret 2017 terhadap 56 mahasiswa Psikologi Universitas Negeri Jakarta, sebanyak 43\% mahasiswa menganggap skripsi sebagai ujian yang berat, menakutkan, dan lainlain, sedangkan 57\% lainnya menganggap skripsi sebagai kewajiban yang harus dijalani untuk meraih gelar S1. Persoalan yang dihadapi diantaranya penentuan masalah, tema, judul penelitian, variabel, subjek penelitian dan referensi serta faktor dosen pembimbing. Selain itu faktor diri seperti perasaan cemas, takut, tertekan, stres, kurang percaya diri dan malas juga menjadi masalah yang sering dialami dalam mengerjakan skripsi. Permasalahan yang dihadapi menjadi tekanan tersendiri bagi mahasiswa untuk menyelesaikan skripsinya, terlebih lagi sebanyak 55 responden menargetkan dirinya untuk menyelesaikan studi tepat waktu dalam empat tahun. Hal tersebut juga diperkuat dengan pernyataan salah satu responden yang merupakan alumni, dimana ada ketakutan tersendiri dalam menyelesaikan skripsi karena besarnya tekanan dan berbagai masalah yang harus dihadapi. Kinansih (dalam Julianti, 2015) menyatakan bahwa mahasiswa yang sedang menyusun skripsi sering kali kesulitan dalam hal menentukan ide penelitian, masalah, judul, sistematika penulisan proposal dan skripsi, literatur, metode penelitian dan analisis data, standar penulisan ilmiah, takut menemui dosen pembimbing, dana dan waktu yang terbatas. Hal tersebut pada akhirnya menimbulkan stres, rendah diri, frustasi dan kehilangan motivasi karena adanya perasaan takut pada diri mahasiswa, atau karena adanya kendala dalam mencari objek penelitian yang cocok dengan tingkat kemampuan mahasiswa. Fenomena takut pada mahasiswa yang sedang skripsi salah satunya adalah takut gagal menyelesaikan skripsi. Harapan untuk dapat lulus tepat waktu dan berbagai permasalahan maupun tekanan yang harus dihadapi menyebabkan timbulnya ketakutan apabila gagal memenuhi berbagai harapan yang ada. Dalam penelitian yang dilakukan Nainggolan (2007) pada mahasiswa Psikologi Universitas Diponegoro ditemukan adanya ketakutan akan kegagalan pada diri mahasiswa. Tuntutan dan harapan yang tinggi terhadap kesuksesan akademik menimbulkan tekanan yang berakibat munculnya rasa takut gagal pada diri mahasiswa. Secara umum ketakutan akan kegagalan merupakan bentuk ketakutan akan terjadinya kegagalan yang dapat menyebabkan konsekuensi memalukan yang dirasakan oleh individu. Hal ini diperkuat oleh Murray dan Atkinson yang menyatakan bahwa ketakutan akan kegagalan merupakan kecenderungan disposisional untukmenghindari kegagalan dikarenakan adanya perasaan malu terhadap kegagalan yang terjadi (Elliot \& Thrash, 2004). Mahasiswa sebagai peserta didik tidak lepas dari berbagai perasaan cemas, takut, gelisah maupun kondisi lainnya yang serupa. Hal tersebut dikarenakan adanya berbagai tuntutan akademik yang harus dijalani serta evaluasi atau penilaian terhadap hasil yang telah dikerjakan. Peserta didik yang secara terus-menerus mendapatkan tuntutan dari orang lain maupun diri sendiri agar mampu berprestasi baik dalam akademik, perasaan gelisah dan takut tersebut dinamakan takut akan kegagalan (Winkel, 2014). Covington \& Olemich menyatakan bahwa pelajar yang memiliki ketakutan akan kegagalan pada dirinya cenderung menganggap kemampuan dirinya tidak dapat berubah. Mereka tidak yakin dengan tujuan yang ditetapkan dan kurang memiliki rasa harga diri yang lepas mengenai tingkat prestasi belajar yang dicapai. Adanya ketakutan gagal pada diri pelajar pada akhirnya membuat mereka kerap bertanyatanya kepada pengajar mengenai apa yang harus dikerjakannya (dalam Winkel, 2014). Hal tersebut menunjukan bahwa individu membutuhkan keberadaan orang lain untuk membicarakan situasi yang sedang dihadapi dan membantu dalam mengurangi kecemasan tentang bagaimana harus bereaksi. Hal ini dikarenakan individu yang takut gagal sering tidak cermat dalam memperkirakan kemampuan dirinya (Nainggolan, 2007). Dalam 
perguruan tinggi, mahasiswa akan dibantu oleh dosen pembimbing dalam penyusunan skripsi. Dosen pembimbing berperan penting dalam memberikan arahan dan masukan kepada mahasiswa terkait dengan penelitian yang dilakukan. Hubungan yang baik antara mahasiswa dan dosen pembimbing tentunya akan menciptakan kondisi yang harmonis sehingga dapat memperlancar proses penyusunan skripsi dan mengurangi tingkat ketakutan mahasiswa. Bair (1999, dalam Dyckman 2005: 357) menyatakan bahwa salah satu faktor yang berpengaruh pada keberhasilan atau kegagalan mahasiswa yang melakukan penelitian sebagai tugas akhir adalah kepuasan hubungan interpersonal dengan penasihat akademik atau mentor. Senada dengan hal tersebut, Nasution juga menyatakan bahwa hubungan yang tidak baik dengan pengajar dapat menghalangi prestasi belajar yang tinggi pada peserta didik (Djaali, 2007). Dalam kasus skripsi, terhambatnya berinteraksi dengan dosen pembimbing sering menjadi keluhan para mahasiswa dalam menyusun skripsi yang pada akhirnya membuat mahasiswa cemas dan takut bila hal tersebut berdampak pada ketidakmampuan menyelesaikan skripsi. Hal ini diakui dengan pernyataan salah satu responden survey berinisial MR yang menyatakan bahwa kesulitan menemui dosen pembimbing dapat menghambat proses pengerjaan skripsi. Berdasarkan penyataan tersebut terlihat bahwa perlu adanya komunikasi yang baik antara mahasiswa dengan dosen pembimbing selama proses skripsi dilakukan. Sarwono (2003) menyatakan bahwa komunikasi merupakan proses pengiriman berita dari satu orang kepada orang lainnya. Mahasiswa yang melakukan interaksi dengan dosen pembimbing termasuk dalam jenis komunikasi interpersonal, dimana komunikasi terjadi pada dua individu. Johnson (dalam Supratiknya, 2009) menyatakan komunikasi interpersonal sebagai suatu hal yang penting dilakukan untuk menciptakan kebahagiaan, diantaranya untuk membantu perkembangan intelektual, identitas diri, pemahaman tentang realitas di sekeliling, dan kesehatan mental. Suatu proses komunikasi akan bisa berjalan efektif apabila penerima mampu menginterpretasikan pesan yang diterimanya dari pemberi pesan (Supratiknya, 2009). Dengan demikian untuk mencapai hasil komunikasi yang efektif perlu adanya hubungan dan kerjasama yang harmonis antar individu. Rakhmat (dalam Gunawati, 2006) menyatakan bahwa komunikasi interpersonal yang efektif antara dua individu dapat menyebabkan timbulnya perasaan senang yang dapat mendorong tumbuhnya sikap saling terbuka. Namun sebaliknya bila komunikasi yang dilakukan tidak berjalan efektif maka akan timbul ketegangan pada pelaku komunikasi. Dalam penelitian Gunawati (2006) ditemukan bahwa komunikasi yang tidak efektif antara mahasiswa dengan dosen pembimbing timbul karena adanya perselisihan pendapat yang pada akhirnya dapat memicu terjadinya ketegangan. Senada dengan hal tersebut Siska, sudardjo \& purnamaningsih (2003) menyatakan bahwa salah satu kemungkinan besar sulitnya komunikasi adalah karena adanya kecemasan diantaranya adalah rasa takut menerima tanggapan berupa penilaian negatif dari komunikan atau orang yang menerima pesan. Hal ini pada akhirnya menyebabkan individu selalu mengharapkan adanya umpan balik dan petunjuk yang jelas dari kualitas pekerjaannya, dimana hal tersebut merupakan karakteristik pelajar yang memiliki takut akan kegagalan (Winkel, 2014). Komunikasi yang terjadi antara mahasiswa dengan dosen pembimbing dapat mempengaruhi kondisi mahasiswa, khususnya rasa takut saat menyusun skripsi. Namun, hal tersebut ternyata tidak sepenuhnya dirasakan oleh mahasiswa yang sedang menyusun skripsi. Berdasarkan survei pada tanggal 26 Maret 2017 terhadap 14 responden mahasiswa Universitas Negeri Jakarta yang sedang mengerjakan skripsi menunjukan hanya 11 mahasiswa yang mengatakan faktor dosen pembimbing mempengaruhi ketakutan dalam penyusunan skripsi, sedangkan 3 mahasiswa lainnya tidak mengatakan demikian. Hal tersebut menunjukkan bahwa dosen pembimbing yang dikatakan menjadi faktor yang memengaruhi ketakutan gagal ternyata tidak sepenuhnya terjadi dan dirasakan oleh mahasiswa dalam menyelesaikan skripsi. Berdasarkan uraian di atas penelitian ini bertujuan untuk melihat hubungan komunikasi interpersonal terhadap dosen pembimbing dengan ketakutan akan kegagalan mahasiswa dalam menyelesaikan skripsi. 


\section{Metode Penelitian}

Jenis penelitian penelitian ini bersifat kuantitatif dengan teknik uji hipotesis korelasi yaitu melibatkan tindkaan pengambilan data untuk menentukan apakah ada hubungan dan tingakat hubungan antara dua variabel atau lebih (Dane, 2000 dalam Sangadji \& Sopiah, 2010)

Populasi dan Sampel Populasi dalam penelitian ini adalah mahasiswa yang sedang mengerjakan skripsi di Universitas Negeri Jakarta. Teknik sampling yang digunakan adalah Nonprobability sampling dengan jenis purposive sampling yaitu teknik penentuan sampel yang dilakukan berdasarkan pertimbangan tertentu. Pertimbangan tertentu yang dimaksud adalah sampel yang memenuhi karakteristik sampel dalam penelitian ini. Adapun sampel dalam penelitian ini adalah sampel dengan karakteristik (1) Mahasiswa aktif S1 Universitas Negeri Jakarta, (2) Dalam proses mengerjakan skripsi, (3) Sudah memiliki dosen pembimbing.

Teknik pengumpulan data komunikasi interpersonal diukur melalui instrumen yang telah dikonstruk oleh peneliti sebelumnya yaitu, Evi Zuhara tahun 2014 dari Universitas Pendidikan Indonesia dalam penelitian tesisnya yang berjudul "Efektivitas Teknik Sosiodrama untuk Meningkatkan Komunikasi Interpersonal Siswa". Instrumen ini disusun berdasarkan teori komunikasi interpersonal menurut DeVito yang meliputi lima aspek yaitu keterbukaan, empati, sikap mendukung, sikap positif dan kesetaraan dengan jumlah aitem sebanyak 48. Instrumen ini kemudian diadaptasi, serta dilakukan pengkajian ulang dan modifikasi untuk menyesuaikan dengan konteks komunikasi interpersonal dengan dosen pembimbing. Dalam penelitian ini terdapat 44 aitem komunikasi interpersonal dengan dosen pembimbing. Ketakutan akan kegagalan diukur melalui instrumen The Performance Failure Appraisal Inventory (PFAI) dari teori ketakutan akan kegagalan menurut Conroy (2001) yang telah diadaptasi ke dalam Bahasa Indonesia oleh Putri Marhaeni tahun 2017 dari Universitas Mercubuana dalam penelitiannya yang berjudul "Hubungan antara Harapan Orangtua dengan Ketakutan akan Kegagalan pada Mahasiswa dengan Status Rentan DO di Universitas aspek yang diukur yaitu ketakutan adanya penghinaan dan rasa malu, ketakutan akan penurunan estimasi diri, ketakutan akan ketidakpastian di masa depan, ketakutan akan hilangnya pengaruh sosial dan ketakutan akan mengecewakan orang yang penting baginya. Hasil uji coba instrumen ini menunjukan koefisien realibilitas sebesar 0,931. Instrumen ini kemudian dikaji kembali dan dimodifikasi untuk menyesuaikan dengan konteks ketakutan akan kegagalan mahasiswa dalam menyelesaikan skripsi. Dalam penelitian ini terdapat 45 aitem yang terdiri dari 38 aitem favorable dan 7 aitem unfavourable .

Validitas dan Reliabilitas Uji Validitas dan reliabilitas dilakukan dengan model Rasch dengan alasan skor yang dihasilkan bukan lagi skor mentah (raw score) melainkan skor murni (true score) yang sudah bebas dari error pengukuran. Selain itu, secara keobjektifannya, model rasch sudah memenuhi standar pengukuran objektif dengan menghasilkan data yang terbebas dari pengaruh subjek, karakteristik penilai (rater) dan karakteristik alat ukur (Sumintono \& Wahyu, 2014). Berdasarkan hasil uji reliabilitas dengan model Rasch, instrumen komunikasi interpersonal memiliki reliabilitas item sebesar 0,78 dan skor raw variance sebesar $31,2 \%$ yang termasuk dalam kategori unidimensi. Adapun berdasarkan hasil uji validitas terdapat 13 item yang gugur dari 44 item yang diujicobakan. Maka dalam penelitian ini terdapat 31 item yang digunakan untuk pengambilan data final. Berdasarkan hasil uji reliabilitas dengann model Rasch, instrumen ketakutan akan kegagalan memiliki reliabilitas 0,96 dan skor raw variance data sebesar $48,7 \%$ yang tergolong dalam instrumen unidimensi. Adapun berdasarkan hasil uji validitas terdapat 4 item yang gugur dari 45 item yang diuji cobakan. Maka dalam penelitian ini terdapat 41 item yang digunakan untuk pengambilan data final yang terdiri dari 35 item favorable dan 6 aitem unfavourable.

\section{Hasil Penelitian dan Diskusi}

Responden yang berpartisipasi mengisi kuesioner secara online yang disebar melalui link googledocs sebanyak 154 orang. Selanjutnya sebanyak 18 responden didrop karena jawabanyang diberikan responden tidak dapat diinterpretasi (outlier), sehingga didapatkan 136 responden yang dijadikan sampel penelitian. 
Tabel 1. Data Responden Berdasarkan Usia

\begin{tabular}{ccc}
\hline Usia & Jumlah & Persentase (\%) \\
\hline 18 tahun & 1 & 0,7 \\
\hline 20 tahun & 1 & 0,7 \\
\hline 21 tahun & 62 & 45,6 \\
\hline 22 tahun & 64 & 47,1 \\
\hline 23 tahun & 7 & 5,2 \\
\hline 24 tahun & 1 & 0,1 \\
\hline Total & $\mathbf{1 3 6}$ & $\mathbf{1 0 0}$
\end{tabular}

Tabel 2. Data Responden Berdasarkan Jenis Kelamin

\begin{tabular}{ccc}
\hline Jenis Kelamin & Jumlah & Persentase (\%) \\
\hline Laki-Laki & 33 & 24,3 \\
\hline Perempuan & 103 & 7,5 \\
\hline Total & $\mathbf{1 3 6}$ & $\mathbf{1 0 0}$ \\
\hline
\end{tabular}

Tabel 3. Data Responden Berdasarkan Angkatan

\begin{tabular}{ccc}
\hline Angkatan & Jumlah & Persentase (\%) \\
\hline 2012 & 4 & 2,9 \\
\hline 2013 & 132 & 97,1 \\
\hline Total & $\mathbf{1 3 6}$ & $\mathbf{1 0 0}$ \\
\hline
\end{tabular}

Tabel 4. Data Responden Berdasarkan asal Fakultas

\begin{tabular}{ccc}
\hline Fakultas & Jumlah & Persentase (\%) \\
\hline FIP & 23 & 16,9 \\
\hline FE & 30 & 22,1 \\
\hline FBS & 11 & 8,1 \\
\hline FIK & 6 & 4,4 \\
\hline FMIPA & 11 & 8,1 \\
\hline FT & 15 & 11,0 \\
\hline FIS & 19 & 14,0 \\
\hline FPPsi & 21 & 15,4 \\
\hline Total & $\mathbf{1 3 6}$ & $\mathbf{1 0 0}$
\end{tabular}

Berdasarkan hasil analisis data didapatkan bahwa variabel komunikasi interpersonal memiliki mean sebesar 2,54, median 2,66, standar deviasi 1,01 , varians 1,02 , nilai minimum 0,02 dan nilai maksimum 3,93. Sedangkan variabel ketakutan akan kegagalan memiliki mean sebesar 0,82 , median 0,71 , standar deviasi 1,33 , varians
1,76 , nilai minimum $-3,45$ dan nilai maksimum 4,39.

Pengkategorian skor dilakukan untuk mengetahui tingkat komunikasi interpersonal dan ketakutan akan kegagalan dari penelitian, yang terdiri dari kategori tinggi dan rendah. berdasarkan nilai mean dari kedua variabel. 
Tabel 5. Tingkat Komuniaksi Interpersonal

\begin{tabular}{ccc}
\hline Kategori & Frekuensi & Persentase $\mathbf{( \% )}$ \\
\hline Rendah & 64 & 47,1 \\
\hline Tinggi & 72 & 52,9 \\
\hline Total & $\mathbf{1 3 6}$ & $\mathbf{1 0 0}$ \\
\hline
\end{tabular}

Tabel 6. Tingkat Ketakutan Akan Kegagalan

\begin{tabular}{ccc}
\hline Kategori & Jumlah & Persentase (\%) \\
\hline Rendah & 73 & 53,7 \\
\hline Tinggi & 63 & 46,3 \\
\hline Total & $\mathbf{1 3 6}$ & $\mathbf{1 0 0}$ \\
\hline
\end{tabular}

Berdasarkan hasil analisis data didapatkan hasil bahwa sebanyak 64 mahasiswa $(47,1 \%)$ memiliki tingkat komunikasi interpersonal yang rendah, sedangkan 72 mahasiswa lainnya $(52,9 \%)$ memiliki tingkat komunikasi interpersonal yang tinggi. Hasilanalisis data ketakutan akan kega- galan menunjukkan sebanyak 73 mahasiswa $(53,7 \%)$ memiliki ketakutan akan kegagalan yang rendah, sedangkan 63 mahasiswa lainnya $(46,3 \%)$ memiliki tingkat ketakutan akan kegagalan yang tinggi.

Tabel 7. Uji Korelasi

\begin{tabular}{|c|c|c|c|}
\hline & & $\begin{array}{c}\text { Komunikasi } \\
\text { Interpersonal }\end{array}$ & $\begin{array}{c}\text { Ketakutan Akan } \\
\text { Kegagalan }\end{array}$ \\
\hline \multirow{2}{*}{$\begin{array}{c}\text { Komunikasi } \\
\text { Interpersonal }\end{array}$} & $\begin{array}{l}\text { Pearson } \\
\text { Correlation }\end{array}$ & 1 & $-0,240$ \\
\hline & $\begin{array}{c}\text { Sig. } \\
\text { (2-tailed) }\end{array}$ & & 0,005 \\
\hline \multirow{2}{*}{$\begin{array}{c}\text { Ketakutan Akan } \\
\text { kegagalan }\end{array}$} & $\begin{array}{c}\text { Pearson } \\
\text { Correlation }\end{array}$ & $-0,240$ & 1 \\
\hline & $\begin{array}{c}\text { Sig. } \\
\text { (2-tailed) }\end{array}$ & 0,005 & \\
\hline
\end{tabular}

Berdasarkan hasil uji hipotesis pada tabel 7 dapat dilihat bahwa variabel komunikasi interpersonal dengan ketakutan akan kegagalan menunjukkan adanya hubungan ataSu korelasi yang signifikan. Dengan melakukan uji hipotesis melalui teknik korelasi bivariat dengan probabilitas $\mathrm{p}<0,05$ terlihat adanya korelasi yang signifikan antara kedua variabel dimana nilai $\mathrm{p}$ sebesar $0,005<0,05$, sehingga dapat disimpulkan bahwa Ho ditolak dengan koefisien korelasi negatif sebesar 0,240. Berdasarkan hal tersebut dapat disimpulkan bahwa terdapat hubungan komunikasi interpersonal terhadap dosen pembimbing dengan ketakutan akan kegagalan pada mahasiswa dalam menyelesaikan skripsi.

Koefisien korelasi antara kedua variabel adalah sebesar -0,240. Koefisien korelasi yang diperoleh bersifat negatif menunjukkan bahwa arah hubungan antara kedua variabel bersifat negatif. Berdasarkan hal tersebut dapat diartikan bahwa semakin tinggi komunikasi interpersonal dengan dosen pembimbing, maka ketakutan akan kegagalan mahasiswa dalam menyelesaikan skripsi akan semakin rendah. Sebaliknya, jikakomunikasi interpersonal dengan dosen pembimbing rendah maka ketakutan akan kegagalan mahasiswa dalam menyelesaikan skripsi akan semakin tinggi.

Ketakutan akan kegagalan adalah bentuk kecemasan dalam suatu situasi yang melibatkan adanya kemungkinan untuk gagal. Hal ini salah satunya dialami oleh mahasiswa dalam menyelesaikan skripsi. Conroy (dalam Nainggolan, 2007) menyatakan bahwa individu yang memiliki perasaan takut gagal selalu menginginkan adanya 
tanggapan yang positif dari orang lain. Nainggolan (2007) dalam penelitiannya menyatakan karakteristik ini terlihat secara langsung dari perilaku mahasiswa yang kerap kali meminta petunjuk secara jelas dan berulang dari pengajar, dimana dalam perguruan tinggi pengajar yang dimaksud adalah dosen. Hal ini disebabkan karena individu yang mengalami takut gagal memiki keraguan bila dihadapkan pada tugas yang baru (Winkel,2014).

Skripsi dapat dikatakan sebagai suatu hal yang baru bagi mahasiswa. Tidak adanya pengalaman sebelumnya dalam melakukan penelitian menyebabkan munculnya keraguan yang dapat memicu perasaan takut pada diri mahasiswa, terlebih lagi dengan dijadikannya skripsi sebagai salah satu syarat kelulusan meraih gelar sarjana. Hal ini semakin menumbuhkan perasaan cemas, takut, dan gelisah pada diri mahasiswa yang pada akhirnya dapat memunculkan perasaan takut gagal dalam menyelesaikan skripsi.

Ketakutan akan kegagalan terjadi karena adanya ketakutan akan efek yang dialami bila gagal dalam melakukan sesuatu. Haber (2013) menyatakan bahwa pelajar yang memiliki ketakutan akan kegagalan sebenarnya takut dengan konsekuensi yang kemungkinan akan dirasakan saat mengalami kegagalan. Secara personal, individu akan merasa malu dengan ketidakmampuannya, kecewa dengan diri sendiri karena harus mengakui kekurangan dan keterbatasan dirinya, serta adanya perasaan bersalah dan tidak berharga jika ia mengalami kegagalan. Secara interpersonal, individu juga akan takut jika ia gagal hal tersebut akan mengecewakan orang tua, mendapat cemooh dari teman hingga hilangnya kepercayaan dan dukungan dari dosen. Secara karir, kegagalan yang dialami akan menurunkan kesempatan individu dalam dunia karir sehingga menurunkan kemungkinan untuk bisa mendapatkan income yang layak dan status sosial yang tepat. Ketiga konsekuensi kegagalan inilah yang menyebabkan individu mengalami perasaan takut gagal, khususnya pada situasi yang melibatkan adanya evaluasi seperti skripsi yang menjadi syarat kelulusan meraih gelar akademik sarjana.

Winkel (2014) menyatakan bahwa individu yang memiliki ketakutan akan kegagalan kerap bertanya mengenai tugas yang harus dikerjakannya. Hal ini pada akhirnya menyebabkan individu membutuhkan orang lain untuk memberikan umpan balik terhadap kualitas hasil pekerjaannya. DeVito (1983, dalam Boyle \& Sandford, 2006: 175) menyatakan bahwa komunikasi interpersonal adalah proses penyampaian pesan yang dapat memberikan umpan balik. Umpan balik yang dihasilkan dari proses komunikasi dapat membantu individu untuk memeroleh respon secara langsung dari orang lain. Umpan balik yang didapatkan secara langsung dapat meningkatkan peluang kesamaan interpretasi pesan sesuai dengan yang diinginkan oleh individu, sehingga komunikasi yang terjalin dapat berjalan efektif. Sebaliknya, bila individu tidak mendapatkan umpan balik, maka proses komunikasi akan terhambat dan menjadi tidak efektif (Suranto AW, 2011). Rendahnya umpan balik yang didapatkan mahasiswa akan semakin meningkatkan perasaan takut gagal karena kebutuhan mahasiswa untuk mendapatkan tanggapan atas hasil pekerjaannya terhalang. Hal ini akan menyebabkan mahasiswa merasa tidak aman, sehingga perasaan cemas, takut, dan gelisah akan meningkat yang pada akhirnya dapat merusak hubungan interpersonal dengan orang lain danturut mempengaruhi motivasi mahasiswa (Desmita, 2011).

Adanya pengaruh positif antara kepemimpinan transformasional dengan keterikatan karyawan dapat terjadi mengingat kepemimpinan transformasional memegang peranan terhadap keterikatan karyawan. Hal ini sejalan dengan penelitian yang dilakukan oleh Daren E. Hancott (2005) yang berjudul "The Relationship between Transformational Leadership and Organizational Performance in the Largest Public Economics in Canada". Daren mengatakan bahwa kepemimpinan transformasional yang dilakukan oleh para pemimpin dan senior managers dalam 26 perusahaan go public di Kanada mampu meningkatkan kinerja perusahaan yang berpengaruh positif terhadap kepuasan kerja karyawan, Hal ini dilihat dari total pendapatan perusahaan tersebut bahwa total pendapatan perusahaan yang menggunakan kepemimpinan transformasional teratas diantara perusahaan go public di Kanada. Sama halnya dengan PT Pertamina (Persero) pemimpinnya mampu menumbuhkan rasa hormat dan keper- 
cayaan dari karyawan juga berhasil memotivasi karyawan sehingga mudah mengarahkan karyawannya untuk mencurahkan seluruh tenaga dan pikirannya bagi kepentingan perusahaan yang mengarahkan kepada apa yang menjadi tujuan perusahaan sehingga membuat Pertamina menjadi BUMN terbesar di Indonesia dan labanya terus meningkat dari tahun ke tahun.

\section{Kesimpulan}

Berdasarkan hasil analisis dan pengujian secara statistik dapat ditarik kesimpulan bahwa terdapat hubungan negatif yang signifikan antara komunikasi interpersonal terhadap dosen pembimbing dengan ketakutan akan kegagalan mahasiswa dalam menyelesaikan skripsi. Arah hubungan antara kedua variabel bersifat negatif, hal tersebut menunjukan apabila tingkat komunikasi interpersonal tinggi maka ketakutan akan kegagalan akan semakin rendah, begitupun sebaliknya.

\section{Daftar Pustaka}

Al-Mighwar, M. (2006). Psikologi Remaja: Petunjuk Bagi Guru dan Orang Tua Bandung. Pustaka Setia.

Aw, Suranto. (2011). Komunikasi Interpersonal. Yogyakarta: Graha Ilmu

Boyle, L. F. \& Sandford, J. (2006). Mixed Messages: English for Communication Studies. Perugia. Morlacchi Editore. https://books.google.co.id/books?isbn=886 0740584 . (10/4/2017)

Conroy, D. E. (2001). Progress in the Development of Multidimensional Measure of Fear of Failure: The Performance Failure Appraisal Inventory (PFAI). Anxiety, Stress, and Coping, 14, 431-452. Doi: 10.1080/10615800108248365

Departemen Pendidikan Nasional. (2015). Kamus Besar Bahasa Indonesia: Edisi 4. Jakarta. Gramedia Pustaka Utama.
Desmita. (2011). Psikologi Perkembangan Peserta Didik. Bandung: Remaja Rosdakarya

Djaali. (2007). Psikologi Pendidikan. Jakarta. Bumi Aksara

Dyckman, L.M. (2005). Fear of Failure and Fear of Finishing: a case study on the emotional aspects of dissertation proposal research, with thoughts on library instruction and graduate student retention. ACRL Twelfth National Conference April 7-10, 351-362. Minnesota

Elliot, A. J., \& Thrash, T. M. (2004). The Intergenerational Transmission of Fear of Failure. Personality and Social Psychology, 30(8), 957-971

Gunawati, R., Hartati, S., \& Listiara, A. (2006). Hubungan antara Efektivtas Komunikasi Mahasiswa-Dosen Pembimbing Utama Skripsi dengan Stres dalam Menyusun Skripsi pada Mahasiswa Program Studi Psikologi Fakultas Kedokteran Universitas Diponegoro. Jurnal Psikologi Universitas Dioponegoro, 3(2), 93115

Haber, F. (2013). Helping Students Overcome Their Fear of Failure. (diakses pada tanggal 6 April 2017). Retrieved from www.eaie.org/blog/helping-studentsovercome-fear-of-failure/

Julianti, R. \& Yulia, A. (2015). Hubungan Komunikasi antara Mahasiswa dan Dosen Pembimbing dengan Stres dalam Menyusun Skripsi pada Mahasiswa S1 Keperawatan STIKES Rannah Minang tahun 2015. Jurnal Ilmiah Ilmu Pendidikan. 15(2), 5762

Sangadji, E. M. \& Sopiah. (2010). Metodologi Penelitian. Yogyakarta: Andi

Sarwono, S. W. (2003). Pengantar Umum Psikologi. Jakarta: Bulan Bintang 
Siska, S, \& Purnamaningsih, E. H. (2003). Kepercayaan Diri dan Kecemasan Komunikasi Interpersonal pada Mahasiswa. Jurnal Psikologi, 2, 67-71

Sumintono, B. \& Widhiarso, W. (2014). Aplikasi Model Rasch untuk Penelitian Ilmu-ilmu Sosial. Cimahi: Trim Komunikata Publishing House Supratiknya, A. (2009). Komunikasi Antarpribadi. Yogyakarta: Kanisius
Winkel, W. S. (2014). Psikologi Pengajaran. Yogyakarta: Sketsa. 